\title{
Maturational stages: comparison of growth and physical capacity indicators in adolescents
}

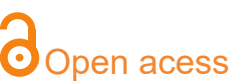

11Federal University of Rio Grande do Norte, Department of Physical Education - Av. Sen Salgado Filho, 3000, Campus Universitário Lagoa Nova Natal/Rio Grande do NorteBrazil

Corresponding author: vanecmpinto@gmail.com

Manuscript received: September 2017 Manuscript accepted: December 2017 Version of record online: March 2018
Vanessa Carla Monteiro Pinto ${ }^{1}$, Petrus Gantois Massa Dias dos Santos ${ }^{1}$, Rafaela Catherine da Silva Cunha de Medeiros ${ }^{1}$, Francisco Emílio Simplício Souza ${ }^{1}$, Thaisys Blanc dos Santos Simões ${ }^{1}$, Renata Poliane Nacer de Carvalho Dantas ${ }^{1}$, Breno Guilherme de Araújo Tinôco Cabral ${ }^{1}$

\begin{abstract}
Introduction: The identification of physical capacity is an important marker related to healthy behavior during childhood and adolescence, in which some factors appear to contribute to motor performance such as maturation and hormonal levels.
\end{abstract}

Objective: To compare growth indicators, physical capacity and hormonal markers according to gender and maturational stage in adolescents.

Methods: Eighty-nine adolescents of both genders aged 10-13 years participated in the study. Sexual maturation was evaluated using the Tanner's self-evaluation method. Physical capacity (explosive strength of upper and lower limbs, upper limb velocity and agility) and hormonal markers (testosterone and estradiol) were evaluated through the chemiluminescence method.

Results: In the comparison by gender, girls had higher weight $(p=0.023)$, height $(p=0.018)$ and fat percentage values ( $p$ $=0.001$ ), while boys presented better motor performance for the explosive strength of upper limbs $(p=0.005)$ and lower limbs $(p=0.011)$, agility $(0.018)$ and upper limb velocity $(p=$ 0.014 ). Regarding maturational stage, boys did not present differences in any variable analyzed; (Stage $V$ versus I), height (stage III, IV and V versus I) and upper limb explosive strength (stage III and IV versus I).

Conclusion: Growth, weight and height, as well as explosive strength of upper limbs were higher in girls at more advanced maturational stages and appear to be gender dependent.

Keywords: testosterone, estradiol, muscle strength, physical aptitude. 


\section{INTRODUCTION}

The identification of physical fitness components in childhood and adolescence is an important marker related to healthy behaviors ${ }^{1}$, since high levels of motor performance in young individuals are usually indicative of active individuals, due to the engagement in several physical activities ${ }^{2}$, evidencing an association between motor development and level of physical activity ${ }^{3}$. Therefore, it is necessary to admit that although the identification of physical capacity is an essential parameter for the elaboration of strategies that more adequately allow the practice of physical activity for adolescents, it is also essential to verify other factors that contribute to the motor function of the pediatric population.

Recently, studies have found that individuals in the same age group with different maturational stages have different growth and motor performance indicators, suggesting that maturation is an important tool to be used in conjunction with growth and motor performance indicators to provide more accurate interpretations of these individuals ${ }^{4-6}$.

During adolescence, the accelerated maturational stage reflects on body growth, strength and power compared to individuals with delayed biological development ${ }^{5,7,8}$, however, with age advancement, these differences tend to be reduced and/or eliminated and contribute to the reduction of participation of adolescents in sports activities ${ }^{9}$.

\section{METHODS}

This correlational cross-sectional study included sample consisting of 89 students of both genders ( 45 boys and 44 girls), aged 10-13 years enrolled in the municipal school system of the city of Natal, Rio Grande do Norte, Brazil. The study was approved by the Ethics Research Committee of the Federal University of Rio Grande do Norte (CEP-UFRN), under protocol No. 1249937/2015 in compliance with Resolution 466/12 of the National Health Council of 12/12/2012, as well as the ethical terms contained in the Helsinki declaration. Parents/guardians gave informed consent and students signed the Consent Term. Subjects who presented any motor and cognitive limitations that made investigation procedures unfeasible were excluded, as well as those undergoing hormonal treatment.

Participants were evaluated in three moments. At the first moment, anthropometric and blood data were collected, being performed in three consecutive days, at the same time. Anthropometric measurements included body mass and height, through an electronic scale (filizola ${ }^{\circledR} 110$, apacity for $150 \mathrm{~kg}$, divisions of $1 / 10 \mathrm{~kg}$ and accuracy of 100 grams) and a stadiometer (Sanny ES2020 ${ }^{\circledR}$ ) with scale of $0.5 \mathrm{~cm}$, respectively, for later identification of body mass index (body mass/height ${ }^{2}$ ). To verify the corrected arm perimeter, the arm perimeter without contraction + triceps skinfold with Harpenden ${ }^{\circledR}$ adipometer (John Bull Indicators Ltd) was measured, as well as the bone diameters: biep $\neg$ icondylar of humerus and femur were collected by means of the Sanny caliper ES2020 ${ }^{\circledR}$. To identify body fat percentage, the specific equation for children and adolescents proposed by Slaughter et al. ${ }^{13}$ was
Somatic maturation, bone age, and sexual maturation are commonly used to assess the adolescent's maturational stage ${ }^{9}$. The method of selfevaluated sexual maturation has been considered an easily applicable tool for the estimation of the pubertal stage of children and adolescents, being based on the application of images of the genitalia and pubic hair in a subjective way to individuals ${ }^{10}$.

Modulation in the process of sexual maturation is influenced by several changes in the endocrine system, mainly by the activation of the hypothalamicpituitary-gonadal axis that induces the progressive release of androgens, such as testosterone, and by the activation of the hypothalamic-pituitary-ovary axis, which results in the production of estrogen ${ }^{9,11}$.

The high level of hormonal concentration during the pubertal process presents a linear relationship with motor performance in adolescence ${ }^{12}$ and should be analyzed in conjunction with other parameters associated with the growth and motor development of this population. Therefore, the objective of the present study was to compare growth indicators, physical capacity and hormonal markers in adolescents according to gender and maturational stage.

used. All procedures were performed by a single evaluator and strictly followed the guidelines of the International Society for Advancement in Kinanthropometry (ISAK).

To evaluate hormonal dosage, a venous puncture in the antecubital region was performed and approximately $10 \mathrm{ml}$ of peripheral blood was collected. From the blood sample, hormonal dosages of testosterone and estrogen of the estradiol type were analyzed by the chemiluminescence method. Collections and analyses were carried out by professionals and specialized laboratories.

To identify the stage of sexual maturation, criteria adopted by Tanner ${ }^{14}$ were used, in which the subject performs the self-evaluation of secondary sexual characteristics, based on the diagnosis of pubic hair. In this method, adolescents' pubertal stage was classified into five strata represented by photographs. This model was validated for young Brazilians by Duke et $a l .{ }^{15}$.

Motor tests included assessment of explosive strength of upper (ESUL) and lower limbs (ESLL), upper limb velocity, and agility. Tests were evaluated on two non-consecutive days, with a minimum interval of 24 hours, being distributed as follows: first day (explosive strength of upper limbs + agility) and on the second day (explosive strength of lower limbs + upper limb velocity). The explosive strength of lower limbs was collected through the counter-movement jump ${ }^{16}$, on a contact platform $\left(\right.$ Cefise $^{\circledR}$ ) connected to Jump Test Pro software 2.10. Explosive strength of upper limbs was identified by the $2 \mathrm{~kg}$ medicine ball throw test, in which the evaluated with both hands against 
the chest was asked to throw it as far as possible ${ }^{17}$, with reliability of $\mathrm{r}=0.84$. Upper limb velocity (VMMSS) was measured using the EUROFIT ${ }^{18}$ test battery, where the shortest execution in two trials time was recorded, with the participation of two evaluators, one for counting cycles and another for timing ${ }^{14,19}$. Finally, agility was measured using the 30-meter test, in which the subject was instructed to run at maximum speed in a course of three meters from one point to another ${ }^{20}$, in which two trials were performed with a 5 minute interval and the best time was recorded, with reliability of $\mathrm{r}=0.88$.

\section{RESULTS}

Among the results presented in table 1, higher values in growth-related measures (mass, height and body fat) were observed in girls, while boys present better performance in motor tests.

\section{Statistical Analysis}

Data normality was verified by the KolmogorvSmirnov test, and the hypothesis of data normality was rejected. Data were shown as median and interquartile range (IQR). The non-parametric Mann-Whitney test was used to compare characteristics, physical capacity and hormonal markers according to gender, and comparison according to the stages of sexual maturation was performed using the Kruskal-Wallis test followed by Post Hoc Dunn's. Analyses were performed using the Statistical Package for Social Sciences - SPPS version 20.0. The significance level was set at $\mathrm{p}<0.05$.

Table 2 shows significant differences for body mass and height of girls according to maturational stage (III, IV and V), demonstrating an increase behavior in these attributes when compared to stage I.

Table 1: Sample characterization and comparison of anthropometric variables, motor tests and hormonal profile of students according to sex.

\begin{tabular}{|c|c|c|c|c|}
\hline & Total $(n=89)$ & Boys (n=45) & Girls $(n=44)$ & \\
\hline & Median (IQR) & Median (IQR) & Median (IQR) & $\mathrm{p}$ \\
\hline CA & $11.35(1.90)$ & $11.60(1.85)$ & $11.20(1.90)$ & 0.56 \\
\hline $\mathrm{BM}(\mathrm{kg})$ & $38.05(14.75)$ & $35.00(12.65)$ & $40.60(16.20)$ & $0.023^{*}$ \\
\hline Height (m) & $1.46(0.10)$ & $1.45(0.08)$ & $1.50(0.14)$ & $0.018^{*}$ \\
\hline Body fat (\%) & $19.0(6.79)$ & $14.20(8.70)$ & $23.80(8.20)$ & $0.001^{*}$ \\
\hline ESUL (m) & $1.70(0.73)$ & $1.80(0.70)$ & $1.50(0.70)$ & $0.005^{*}$ \\
\hline ESLL (cm) & $21.95(5.02)$ & $22.90(4.30)$ & $20.90(4.70)$ & $0.011^{*}$ \\
\hline Agility (s) & $8.27(0.98)$ & $8.00(0.86)$ & $8.46(1.05)$ & $0.018^{*}$ \\
\hline ULV (s) & $14.12(3.30)$ & $14.09(7.62)$ & $14.26(2.49)$ & $0.014^{*}$ \\
\hline Testosterone (ng/dl) & $3.48(4.51)$ & $3.94(11.45)$ & $3.52(1.92)$ & $0.005^{*}$ \\
\hline \multirow[t]{2}{*}{ Estradiol (ng/dl) } & $1.68(4.94)$ & - (18.30) & $4.25(4.77)$ & $0.002^{*}$ \\
\hline & Total (\%) & Boys (\%) & Girls (\%) & \\
\hline Stage I & 33.3 & 32.6 & 34.1 & \\
\hline Stage II & 33.3 & 39.1 & 27.3 & \\
\hline Stage III & 17.8 & 10.9 & 25.0 & \\
\hline Stage IV & 10.0 & 10.9 & 9.1 & \\
\hline Stage V & 5.6 & 6.5 & 4.5 & \\
\hline
\end{tabular}

$\mathrm{IQR}=$ interquartile range; $\mathrm{CA}=$ chronological age; $\mathrm{BM}=$ body mass; \% $\mathrm{F}$ = fat percentage; $\mathrm{ESUL}=$ explosive strength of upper limbs; $E S L L=$ explosive strength of lower limbs; ULV = upper limb velocity; ${ }^{*}=$ significant difference $(p<0.05)$.

Table 2: Comparison of anthropometric characteristics according to the maturational stages of boys and girls (median and IQR)

\begin{tabular}{|c|c|c|c|c|c|c|}
\hline Variables- Boys & Stage I & Stage II & Stage III & Stage IV & Stage V & $\mathbf{p}$ \\
\hline $\mathrm{BM}(\mathrm{kg})$ & $31.40(5.20)$ & 36.10 (13.98) & $35.25(16.80)$ & $38.80(20.75)$ & $45.00(4.95)$ & 0.158 \\
\hline Height (m) & $1.42(0.08)$ & $1.44(0.09)$ & $1.45(0.07)$ & $1.50(0.19)$ & $1.47(0.05)$ & 0.579 \\
\hline BMI $\left(k g / m^{2}\right)$ & $15.54(2.78)$ & $16.63(3.35)$ & $17.08(7.21)$ & $17.24(7.70)$ & $20.91(0.38)$ & 0.196 \\
\hline Body fat (\%) & $13.50(6.00)$ & $14.25(8.58)$ & $15.90(20.28)$ & $14.20(16.75)$ & $22.10(0.76)$ & 0.191 \\
\hline Variables- Girls & Stage I & Stage II & Stage III & Stage IV & Stage V & $\mathrm{p}$ \\
\hline $\mathrm{BM}(\mathrm{kg})$ & 35.60 (15.42) & 38.75 (10.92) & $46.70(11.60)$ & $50.35(9.18)$ & $59.20(5.89)^{*}$ & 0.049 \\
\hline Height (m) & $1.43(0.16)$ & $1.48(0.13)$ & $1.52(0.09)^{*}$ & $1.59(0.06)^{*}$ & $1.63(0.11)^{*}$ & 0.002 \\
\hline BMI $\left(\mathrm{kg} / \mathrm{m}^{2}\right)$ & $16.41(3.54)$ & $17.46(3.22)$ & $19.46(3.21)$ & $19.32(3.47)$ & $22.00(0.77)$ & 0.655 \\
\hline Body fat (\%) & 21.15 (9.88) & $23.50(9.53)$ & $24.50(6.50)$ & $26.20(7.32)$ & $24.25(1.52)$ & 0.941 \\
\hline
\end{tabular}

$\mathrm{BM}=$ body mass; $\mathrm{BMI}=$ body mass index; ${ }^{*}=$ difference between stage I $\mathrm{p}<0.05$. 
Figures 1 and 2 present the comparison of physical tests according to the maturational stages of boys and girls, respectively. There was no difference in performance in any physical test according to the stages of sexual maturation of boys $(p>0.05)$. On the other hand, girls at maturational stage III $(E S U L=1.94+0.59 \mathrm{~m})$ and at maturational stage IV $($ ESUL $=2.01+0.39 \mathrm{~m})$ achieved better performances in the explosive strength of upper limbs than girls classified at maturational stage I.
Figure 3 shows the comparison of hormonal markers, testosterone and estradiol, according to the maturational stage of boys and girls, respectively. No significant differences were observed between testosterone concentration and estradiol according to maturational stages $(\mathrm{p}>0.05)$.
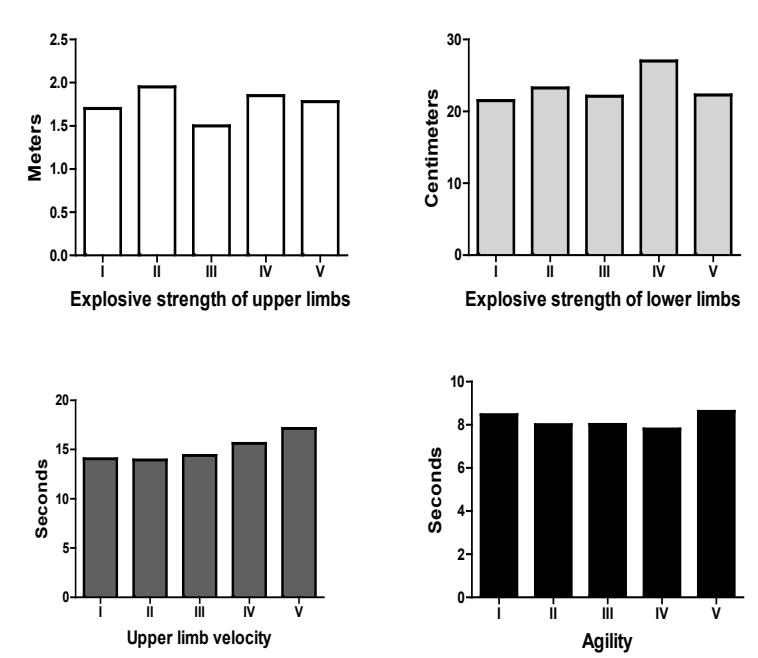

Figure 1: Comparison of physical tests according to the maturational stage of boys. ESUL = explosive strength of upper limbs; ESLL = explosive strength of lower limbs; VMS = upper limb velocity.

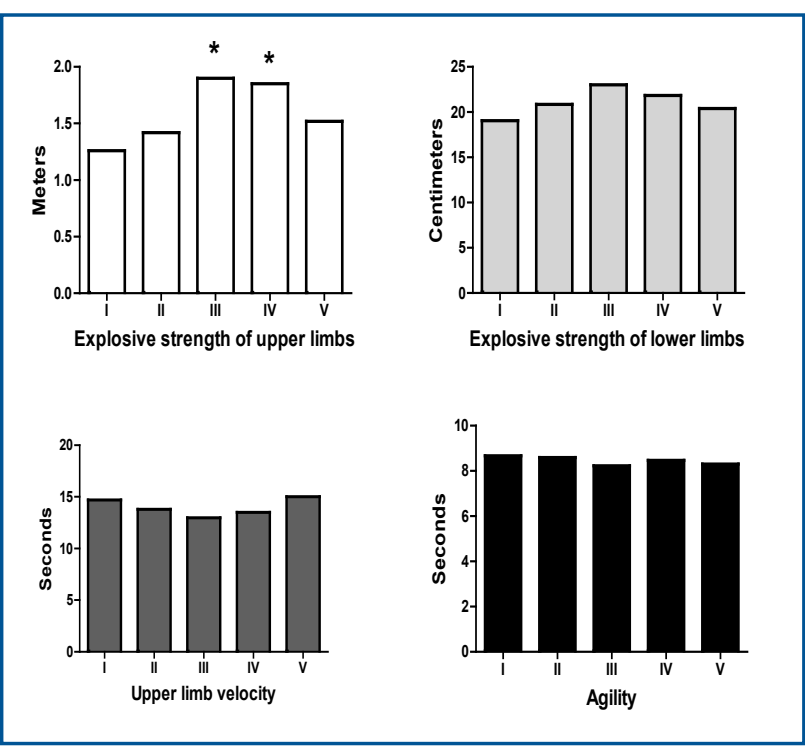

Figure 2: Comparison of physical tests according to the maturational stage of girls. FMS = explosive strength of upper limbs; FMI = explosive strength of lower limbs; VMS = upper limb velocity; * = significant difference with stage I. a

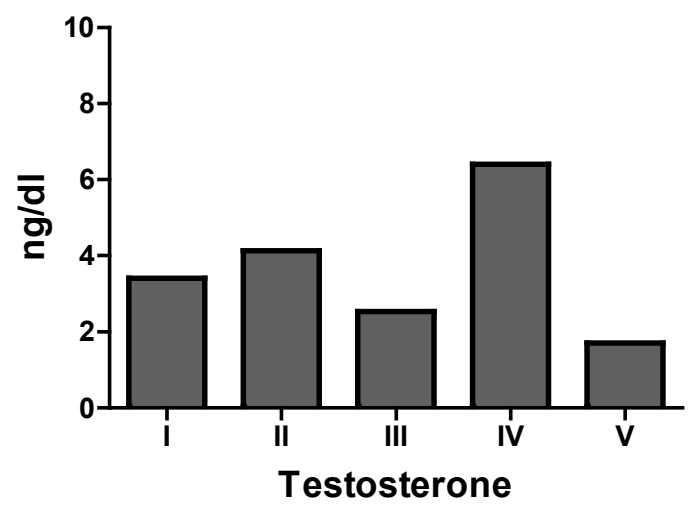

b

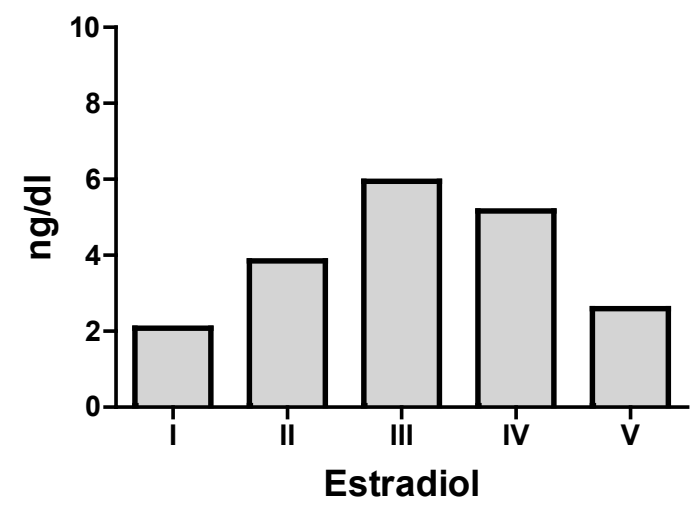

Figure 3: Comparison of hormonal markers according to the maturational stage of boys (a) and girls (b). 


\section{DISCUSSION}

The main findings of the present study indicated significant differences in anthropometric variables and explosive strength of upper limbs according to stages of sexual maturation of girls. On the other hand, no significant differences were observed in any dependent variable for boys.

In the comparison between genders, it was observed that girls presented higher mass, body height and body fat (\%) in relation to boys. In fact, it is well established that during the maturation process, girls are affected earlier $(\sim 11$ years $)$ than boys $(\sim 13 \text { years })^{21}$, and that estrogen, hormone responsible for the development of female sexual characteristics, promotes pelvic enlargement, breast development and increase of fat stores for menarche, which results in increased body mass ${ }^{22}$. On the other hand, greater performance was found for boys in all physical tests evaluated in the present study (i.e., explosive strength of upper and lower limbs, upper limb velocity and agility).

It is possible to attribute this higher performance to the action of testosterone, which plays an important role in the performance of physical tests, especially those related to strength ${ }^{23}$. In addition, it is speculated that these differences between genders may also be related to the social and cultural context, which indicate that girls participate in less physical activities (moderate/vigorous intensities) and sports than boys, reflecting in lower performance in physical tests; however, the best motor gestures were found for boys ${ }^{2}$.

Contrary to our initial hypothesis, no difference was observed in the performance of physical tests for boys and in the hormonal concentration in both genders according to the maturational stage. Based on the premise that the maturational process is guided by the increase in the circulation of testosterone and estrogen hormones in boys and girls, respectively ${ }^{21}$, it would be reasonable to suppose that the more advanced stages of sexual maturation would present higher concentration of these hormones and, consequently, better performance in physical tests ${ }^{24}$.

However, this premise was not supported by the results found in this study and diverges from previous studies, which have demonstrated that in more advanced maturational stages, physical performance is higher compared to individuals with delayed maturational stage $^{5,6}$, as well as the hormonal concentration levels ${ }^{25}$. Vidal-Linhares et al. ${ }^{6}$, observed a significant tendency to increase physical capacity in parallel with the advancement of the maturational stage in male adolescents. When verifying the performance of the explosive strength of upper and lower limbs of young volleyball players, higher performance was observed in adolescents of both genders with accelerated maturational stage in relation to their pairs with delayed maturation, using a model that estimates bone age. Recently, a study conducted by Pinto et al. ${ }^{25}$, demonstrated higher physical performance, testosterone and estradiol concentration in adolescents with higher maturational stage, also using the model that estimates bone age.

In view of these findings, it is speculated that although self-evaluated sexual maturation is a valid and widely used method, there is discrepancy in the identification of intermediate stages (II, III and IV), which may result in overestimated information. There are indications of low association between self-evaluation and objective method (performed by specialists) in literature, presenting low agreement between self-evaluation and evaluation performed by specialists ${ }^{10}$.

In addition, Fidelix et al. ${ }^{26}$ suggest that this method may suffer cultural influences regarding stage choices. Based on this premise, it is possible to explain the lack of increase in testosterone levels in boys, considering that boys' peak testosterone occurs around 13 years of age ${ }^{21}$ and the mean age of our sample is $\sim 11$ years (data not shown). In relation to girls, a possible justification for this stabilization of estradiol concentration during maturational advancement may be associated with fat percentage, which presents high values from stage I. Zhai et al. ${ }^{27}$ reported that fat stores are able to influence estradiol levels through conversion mechanisms. Therefore, it is suggested that, in parallel with subjective methods, objective methods to estimate the maturational stage of adolescents should also be applied.

In the present study, differences were identified in girls only in the explosive strength of upper limbs for those in stages III and IV, and higher performance was observed in relation to those without pubertal signs (stage I). These data corroborate the assertion that maturation can lead to changes in upper limb strength production ${ }^{25,28}$.

Thus, sexual maturation should be considered in activities involving explosive strength of upper limbs, mainly in sports practices, and not only the chronological age of young individuals, because as observed in our study, subjects who are of the same age can have distinct upper limb strength. On the other hand, differences were not identified for the explosive strength of lower limbs in girls, and this result was also found in literature, when it did not identify modifications in the physical capacity in subjects classified as pubertal and post-pubertal ${ }^{25,29}$. In this sense, the performance of the explosive strength of lower limbs appears not to be influenced by sexual maturation, and that during puberty, there is no increase in this attribute in female adolescents who are not engaged in physical training for this purpose ${ }^{28}$.

This fact was supported by Quatman et al. ${ }^{29}$, who, in a two-year longitudinal study with female adolescents, did not report significant improvements in vertical jump height, even with changes in the maturational stage of adolescents. These data suggest that other factors are associated with the improvement of the explosive strength of lower limbs that does not necessarily involve the maturational process, and that specific training is necessary to improve the synchronization of motor units, greater use of elastic energy in the knee extensor muscles from the elongation-shortening cycle efficiency ${ }^{30}$.

Considering these informations, it is worth highlighting that the present study presents relevant information to the exercise science and to the pediatric population, especially with respect to the evaluation of 
maturation as a parameter for the elaboration of strategies for the practice of physical activity, since subjects with the same chronological age may present different performance in upper limb strength.

Therefore, the identification of maturation can support the development of strategies that promote greater adherence to physical activities, taking into account their

\section{CONCLUSION}

In conclusion, growth, weight and height indicators, as well as the explosive strength of upper limbs were higher in girls at more advanced maturational stages. Thus, data suggest that physical education professionals should take into account, during the development of physical exercise programs, the biological development of individuals and potentialities and motor limitations. Nevertheless, it is important to highlight that the method of self-evaluated sexual maturation, even though widely used and validated, can suffer external and body awareness influences, which could overestimate the adolescents' responses and, thus, be considered a possible study limitation.

not only chronological age as evaluative standard, but it is also necessary to consider other aspects such as gender. In addition, no differences were observed for boys in any of the analyzed variables, which may be related to possible external influences inherent to the self-evaluation method.

\section{REFERENCES}

1. Vedul-Kjelsås V, Sigmundsson H, Stensdotter AK, Haga M. The relationship between motor competence, physical fitness and self-perception in children. Child Care Health Dev. 2012;38(3):394-402. DOI: http://dx.doi.org/10.1111/j.1365-2214.2011.01275

2. Spessato BC, Gabbard C, Valentini N, Rudisill M. Gender differences in Brazilian children's fundamental movement skill performance. Early Child Dev Care. 2013;183(7):916-23.

DOI: http://dx.doi.org/10.1080/03004430.2012.689761

3. Vandorpe B, Vandendriessche J, Lefevre J, Pion J, Vaeyens R, Matthys S, et al. The KörperkoordinationsTest für Kinder: Reference values and suitability for 6-12-year-old children in Flanders. Scand J Med Sci Sport. 2011;21(3):378-88. DOI: http://dx.doi.org/10.1111/j.1600-0838.2009.01067

4. Gouvea M, Cyrino ES, Ribeiro AS, Silva DRP, Ohara D, Valente-Dos-Santos J, et al. Influence of skeletal maturity on size, function and sport-specific technical skills in youth soccer players. Int J Sports Med. 2016;37(6):464-9. DOI: http://dx.doi.org/10.1055/s-0035-1569370

5. Gantois P, Pinto VCM, Castro KR, João PV, Dantas PMS, Cabral BGAT. Skeletal age and explosive strength in young volleyball players. Rev Bras Cineantropom Desempenho Hum. 2017;17(3):331-42. DOI: http://dx.doi.org/10.5007/1980-0037.2017v19n3p331

6. Vidal-Linhares R, Barros-Costa M, Fernandes Filho J. A influência do desenvolvimento sexual sobre as qualidades físicas básicas de meninos adolescentes. Rev Salud Pública. 2015;17(4):489-99.

DOI: http://dx.doi.org/10.15446/rsap.v17n4.30832

7. Lefevre J, Beunen G, Steens G, Claessens A, Renson R. Motor performance during adolescence and age thirty as related to age at peak height velocity. Ann Hum Biol. 1990;17(5):423-35.

8. Rodrigues Junior MA, Agostinete RR, Marco RL, Ito IH, Santos MRR, Fernandes RA. Ganho de densidade mineral óssea relacionado à prática de basquetebol em meninos: estudo de coorte. J Hum Growth Dev. 2017;27(1):71-6. DOI: http://dx.doi.org/10.7322/jhgd.127655

9. Malina RM, Rogol AD, Cumming SP, Silva MJC, Figueiredo AJ. Biological maturation of youth athletes: assessment and implications. Br J Sports Med. 2015;49(13):852-9. DOI: http://dx.doi.org/10.1136/bjsports-2015-094623

10. Azevedo JCV, Brasil LMP, Macedo TBMA, Pedrosa LFC, Arrais RF. Comparison between objective assessment and self-assessment of sexual maturation in children and adolescents. J Pediatr (Rio J). 2009;85(2):135-42. DOI: http://dx.doi.org/10.2223/JPED.1875

11. Baldari C, Di Luigi L, Emerenziani GP, Gallotta MC, Sgrò P, Guidetti L. Is explosive performance influenced by androgen concentrations in young male soccer players? Br J Sports Med. 2009;43(3):1914. DOI: http://dx.doi.org/10.1136/bjsm.2007.040386

12. Lowe DA, Baltgalvis KA, Greising SM. Mechanisms behind estrogen's beneficial effect on muscle strength in females. Exerc Sport Sci Rev. 2010;38(2):61-7. DOI: http://dx.doi.org/10.1097/JES.0b013e3181d496bc

13. Slaughter M, Lohman T, Boileau R, Horswill C, Stillman RJ, Van Loan MD, et al. Skinfold equations for estimation of body fatness in children and youth. Hum Biol. 1988;60(5);709-23. 
14. Tanner J. Growth at adolescence. 2nd ed. Thomas: Springfield; 1962.

15. Duke PM, Litt IF, Gross RT. Adolescent self-assessment of sexual maturation. Pediatrics. 1980;66(6):918-20.

16. Komi P V, Bosco C. Utilization of stored elastic energy in leg extensor muscles by men and women. Med Sci Sports. 1978;10(4):261-5. DOI: http://dx.doi.org/10.1080/00140137208924444

17. Gaya A, Silva G. Projeto Esporte Brasil PROESP: Manual de aplicação de medidas e testes, normas e critérios de avaliação. PROESP; 2007.

18. Council of Europe. Committee of Experts on Sports Research. Eurofit: handbook for the Eurofit tests of physical fitness. 2nd ed. Strasbourg: 1993.

19. Marins, JCB, Giannichi RS. Avaliação e prescrição de atividade física: guia prático. 3ed. Rio de Janeiro: Shape, 2003.

20. Buligin MA. Models for improving a volleyballer's physical qualities. Sov Sport Rev. 1981;16:43-45.

21. Rogol AD, Roemmich JN, Clark PA. Growth at puberty. J Adolesc Health. 2002;31(6 Suppl):192-200.

22. Silva DAS, Pelegrini A, Petroski EL, Gaya ACA. Comparison between the growth of Brazilian children and adolescents and the reference growth charts: data from a Brazilian project. J Pediatr (Rio J). 2010;86(2):115-20. DOI: http://dx.doi.org/10.2223/JPED.197523.

23. Garcés C, Oya I, López-Simón L, Cano B, Schoppen S, Gil A, et al. Hormone levels in 12- to 15-year-old boys and girls in Spain and their relationship with anthropometric variables. Clin Biochem. 2008;41(78):621-4. DOI: http://dx.doi.org/10.1016/j.clinbiochem.2008.01.003

24. Goswami B, Singha Roy A, Dalui R, Bandyopadhyay A. Impact of pubertal growth on physical fitness. Am J Sport Sci Med. 2014;2(5A):34-9. DOI: http://dx.doi.org/10.12691/ajssm-2-5A-8

25. Pinto VCM, Santos PGMD, Dantas MP, Araújo JPF, Cabral SAT, Cabral BGAT. Relationship between bone age, hormonal markers and physical capacity in adolescents. J Hum Growth Dev. 2017;27(1):7783. DOI: http://dx.doi.org/10.7322/jhgd.127658

26. Fidelix YL, Minatto G, Ribeiro RR, Santos KD, Petroski EL. Dados sociodemográficos, estado nutricional e maturação sexual de escolares do sexo masculino: Exposição à insatisfação com a imagem corporal. Rev da Educ Fis. 2013;24(1):83-92. DOI: http://dx.doi.org/10.4025/reveducfis.v24.1.17353

27. Zhai L, Liu J, Zhao J, Liu J, Bai Y, Jia L, et al. Association of Obesity with Onset of Puberty and Sex Hormones in Chinese Girls: A 4-Year Longitudinal Study. PLoS One. 2015;10(8):e0134656. DOI: http://dx.doi.org/10.1371/journal.pone.0134656

28. Silva DAS, Oliveira ACC. Impacto da maturação sexual na força de membros superiores e inferiores em adolescentes. Rev Bras Cineantropometria e Desempenho Hum. 2010;12(3):144-50. DOI: http://dx.doi.org/10.5007/1980-0037.2010v12n3p144

29. Quatman CE, Ford KR, Myer GD, Hewett TE. Maturation leads to gender differences in landing force and vertical jump performance: a longitudinal study. Am J Sports Med. 2006;34(5):806-13. DOI: http://dx.doi.org/10.1177/0363546505281916

30. Stojanović E, Ristić V, McMaster DT, Milanović Z. Effect of plyometric training on vertical jump performance in female athletes: a systematic review and meta-analysis. Sport Med. 2017;47(5):975-86. DOI: http://dx.doi.org/10.1007/s40279-016-0634-6 


\section{Resumo}

Introdução: A identificação da capacidade física se apresenta como importante marcador relacionado ao comportamento saudável durante a infância e adolescência, no qual alguns fatores aparentam contribuir para o desempenho motor como a maturação e níveis hormonais.

Objetivo: Comparar indicadores de crescimento, capacidades físicas e marcadores hormonais de acordo com o sexo e estágio maturacional em adolescentes.

Método: Participaram do estudo 89 adolescentes de ambos os sexos de 10 a 13 anos. Foram avaliados a maturação sexual, obtida através do método de autoavaliação de Tanner, capacidades físicas (força explosiva de membros superiores e inferiores, velocidade de membros superiores e agilidade) e marcadores hormonais (testosterona e estradiol) através do método de quimiluminescência.

Resultados: Na comparação pelo sexo, as meninas obtiveram maiores valores para o peso $(p=0,023)$, estatura $(p=0,018)$ e percentual de gordura $(p=0,001)$, enquanto que os meninos apresentaram melhor rendimento motor para a força explosiva de membros superiores $(p=0,005)$ e inferiores $(p=0,011)$, agilidade $(0,018)$ e velocidade de membros superiores $(p=0,014)$. Em relação ao estágio maturacional os meninos não apresentaram diferenças em nenhuma variável analisada; enquanto as meninas em estágio maturacional mais avançado apresentaram maiores valores para o peso (estágio $\mathrm{V}$ versus $\mathrm{I}$ ), estatura (estágio III, IV e V versus I) e força explosiva de membros superiores (estágio III e IV versus I).

Conclusão: Os indicadores de crescimento, peso e estatura, bem como a força explosiva de membros superiores foram mais elevados nas meninas em estágios maturacionais mais avançados e parecem ser dependentes do sexo.

Palavras-chave: testosterona, estradiol, força muscular, aptidão física.

${ }^{-}$The authors (2018), this article is distributed under the terms of the Creative Commons Attribution 4.0 International License (http://creativecommons.org/licenses/by/4.0/), which permits unrestricted use, distribution, and reproduction in any medium, provided you give appropriate credit to the original author(s) and the source, provide a link to the Creative Commons license, and indicate if changes were made. The Creative Commons Public Domain Dedication waiver (http://creativecommons.org/publicdomain/ zero/1.0/) applies to the data made available in this article, unless otherwise stated. 